\title{
EFEITO DOS SAIS BILIARES EM BACTÉRIAS LÁCTICAS ISOLADAS DE QUEIJO MINAS PADRÃO ARTESANAL
}

\section{Alysson Vinícius Braga*, Ana Paula Ferreira, Paulo Afonso Granjeiro, Juliana Teixeira de Magalhães}

Universidade Federal de São João Del Rei, Divinópolis/MG

*e-mail: alyssonviniciuss@hotmail.com

\section{Resumo}

Microrganismos como as bactérias lácticas podem ter propriedades que auxiliam na saúde e bem-estar dos consumidores. Para que possam exercer seu efeito probiótico, esses microrganismos precisam atingir o trato intestinal em quantidades consideráveis, ao qual deverão permanecer aderidas. Por isso, é fundamental que elas resistam, quando ingeridas, às barreiras biológicas, como a ação dos sais biliares. Neste sentido, o objetivo do presente trabalho foi verificar a resistência de 25 bactérias lácticas, isoladas de Queijo Minas Padrão artesanal, a diferentes concentrações de sais biliares através da metodologia de difusão em ágar. As bactérias foram plaqueadas em ágar Man Rogosa and Sharpe (MRS) e neste meio foram feitos poços de $8 \mathrm{~mm}$, nos quais foram adicionadas as concentrações de sais biliares de $0,15,0,3,0,6$ e $1 \%$. As placas foram incubadas a $37^{\circ} \mathrm{C}$ durante 24 horas para medida dos halos de inibição formados. Realizaram-se três repetições. A variação de halo de inibição ocorreu de $8,0 \mathrm{~mm}$ até $22,7 \mathrm{~mm}$ para a maior concentração de sais biliares e de $8,0 \mathrm{~mm}$ até $9,3 \mathrm{~mm}$ para a menor. As bactérias denominadas QS9, Can8, Can9, P2 e G9 foram as que apresentaram maior resistência aos sais biliares, pois apresentaram os menores halos de inibição, o que demonstra que são capazes de sobreviver em concentrações de sais biliares bem acima daquelas as quais seriam submetidas durante o processo digestivo, ou seja, de $0,3 \%$ a $0,5 \%$ em um ser humano. Portanto, estes isolados se mostraram promissores candidatos a probióticos, e serão selecionados para prosseguirem os experimentos de confirmação da capacidade probiótica.

Palavras chaves: sais biliares, bactérias lácticas, probióticos Agradecimentos: FAPEMIG, CNPq, UFSJ 